China Perspectives

57 | january - february 2005

Varia

\title{
Democracy at a Stalemate
}

The September 2004 Legco Elections in Hong Kong

\section{Ma Ngok}

\section{OpenEdition}

\section{Journals}

Édition électronique

URL : http://journals.openedition.org/chinaperspectives/1117

DOI : 10.4000/chinaperspectives. 1117

ISSN : 1996-4617

Éditeur

Centre d'étude français sur la Chine contemporaine

Édition imprimée

Date de publication : 15 février 2005

ISSN : 2070-3449

\section{Référence électronique}

Ma Ngok, « Democracy at a Stalemate », China Perspectives [En ligne], 57 | january - february 2005, mis en ligne le 01 février 2008, consulté le 28 octobre 2019. URL : http://journals.openedition.org/ chinaperspectives/1117; DOI : 10.4000/chinaperspectives.1117

Ce document a été généré automatiquement le 28 octobre 2019

(c) All rights reserved 


\title{
Democracy at a Stalemate
}

\author{
The September 2004 Legco Elections in Hong Kong
}

\section{Ma Ngok}

Despite a recent rekindling of the democracy movement in the territory Hong Kong's Democrats failed to make much ground in the Legco elections of September last year. They had hoped to capture a majority in the semi-democratic legislature, but managed to win only 25 out of 60 seats. This disappointing result has weakened their bargaining power with the Central People's Government with respect to future political reforms in Hong Kong. Peking may have breathed a sigh of relief at this outcome, but the governing crisis of the Hong Kong Special Administrative Region (HKSAR) is showing little sign of improving. The failure of the Democrats to gain a majority may further delay political reform in Hong Kong, and this will serve to prolong or aggravate the crisis of governance in the SAR.

2 The September 2004 elections came on the heels of successive massive demonstrations in Hong Kong in support of more rapid democratisation. This article will first discuss the recent political developments in Hong Kong in the lead-up to the elections, showing how a rebirth of the democracy movement in Hong Kong has led to Peking's change in its policy towards Hong Kong. Specifically, Peking has become more pro-active in affairs regarding Hong Kong after 2003, trying hard to prevent the Democrats from gaining a majority in the 2004 elections. The Democrats saw the elections as a referendum on democracy for Hong Kong, but failed to make a marked improvement in overall level of voter support in the campaign. Although the democrats managed to get $60 \%$ of the popular vote, the semi-democratic nature of the system prevented them from seizing a majority. The elections returned a more pluralised legislature, with the government's majority diminished but secure, which may mean further challenges and governance difficulties for the SAR government.

From Article 23 to articles 45 and 68: the rebirth of the democracy movement

3 Hong Kong may have one of the slowest paces of democratisation in the contemporary world. While a colony, the all-powerful colonial Governor was appointed from London, who, up to 1985, appointed his major officials and all Legislative Council (Legco) members. By Legco appointment system, the colonial government co-opted business 
and professional leaders to defuse possible social opposition to government policy, and built a "synarchy" of colonial bureaucrats and local elites ${ }^{1}$. After the Sino-British Joint Declaration of 1984 made it imperative for Britain to return Hong Kong to China, the British began to push for gradual democratisation in Hong Kong. The number of popularly elected seats increased very slowly: it took 13 years for the proportion of popularly elected seats to increase from 30\% in 1991 to $50 \%$ in 2004 (see Table 1), the remaining 50\% returned by "functional constituencies" that represented major business and professional groups. The SAR Chief Executive (CE), who inherited most of the powers of the colonial Governor, is elected by an Election Committee of 800 people that represented mostly the major business and professional groups.

1. The composition of the Hong Kong Legislative Council

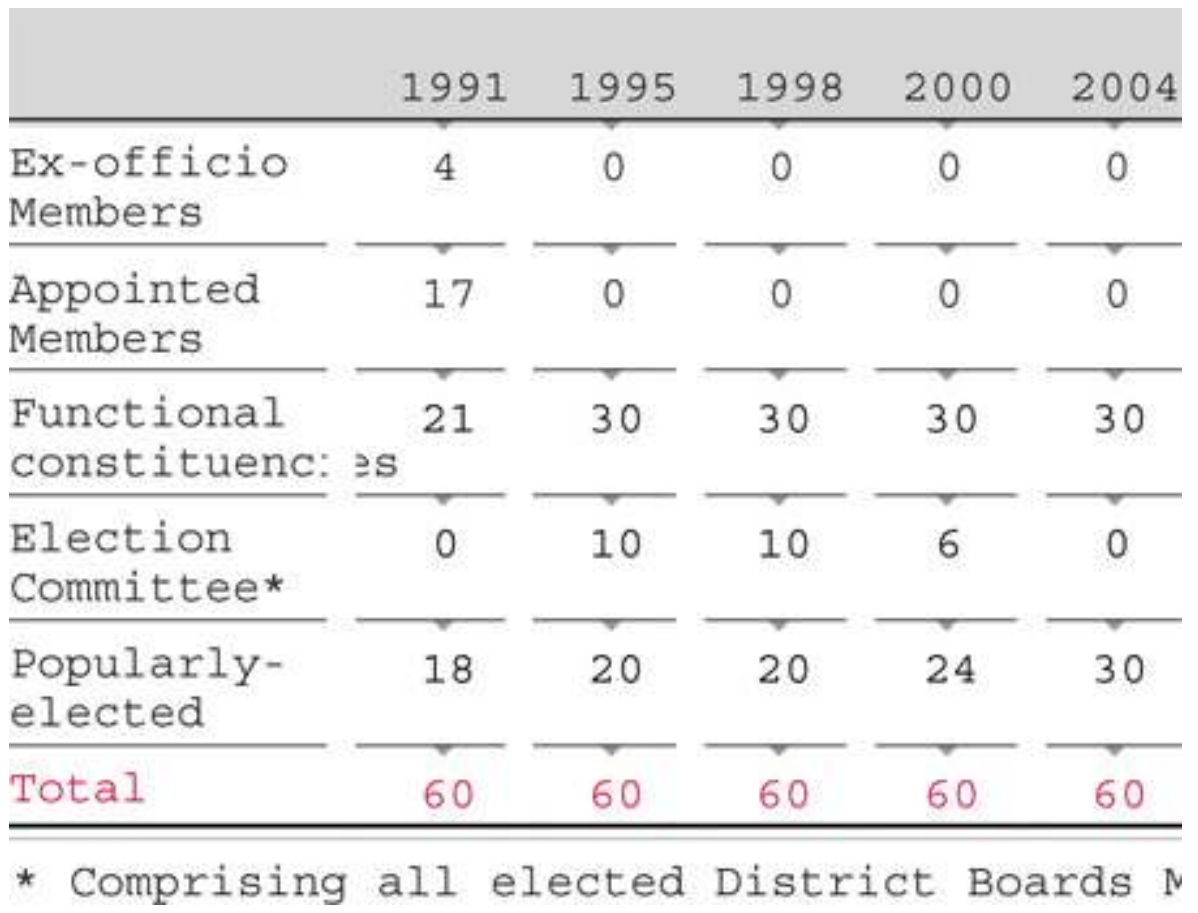

Decolonisation and gradual democratisation from above in the 1980s promptly gave rise to a local democracy movement. In the late 1980s, 95 groups from the civil society formed a grand coalition of democrats to fight for a more democratic political formula in the Basic Law, Hong Kong's mini-constitution after 19972. Their efforts were thwarted by a holy alliance of Peking and local business conservatives, who claimed that rapid democratisation would bring instability and/or a welfare state, hurting Hong Kong's status as a low-tax capitalist haven ${ }^{3}$. The Basic Law, promulgated in 1990, stipulated a very gradual pace of democratisation, although it does guarantee "ultimate" election of the $\mathrm{CE}$ and the whole of Legco by universal suffrage. The democracy movement in Hong Kong, meanwhile, was spurred on by the Tiananmen crackdown of 1989. One million Hong Kong people took to the streets that spring to support the mainland movement. Support for democracy, fear of China's intervention after 1997, and defending Hong Kong's freedom and autonomy suddenly became synonyms. In the partially-democratic Legco elections in 1991 and 1995, the democrats enjoyed great success in the popular elections, taking up a sizeable minority in the Legco. 
5 The democracy movement lost its momentum somewhat after 1997, partly because of the lack of ostensible intervention from the mainland. With great restraint, Peking's leaders more or less let the SAR government run its own course after 1997. Running on a largely anti-communist platform, the Democrats' political agenda began to lose some of its appeal after 1997. An economic downturn triggered by the Asian financial crisis also turned the people's attention away from politics to bread-and-butter issues ${ }^{4}$. Differences within the pro-democracy camp surfaced concerning the future direction of the democracy movement, leading to infighting and factional struggles that hurt the moral image of the democrats 5 . The 2000 Legco election marked a low point of the prodemocracy forces in Hong Kong, with pro-democracy candidates getting $57 \%$ of the popular vote (yes, $57 \%$ of the votes was a historic low for the democrats in Hong Kong), with the pro-Peking Democratic Alliance for the Betterment of Hong Kong (DAB) getting $30 \%$, greatly closing the gap with the democrats. Political conservatives have dominated the functional constituencies (FCs) since their inception in 1985 as the business sector in Hong Kong has generally been politically conservative, and most wished not to antagonise the Central or the SAR governments on the issue of democracy, for fear of hurting their business interests in the mainland. With the FCs taking up half of the Legco seats after 1997, the SAR government enjoyed majority support in Legco from 1997 to 2004, with the democrats getting about 21-22 seats in the 60-strong Legco.

6 For the ailing democracy movement in Hong Kong, the SAR government's proposal in 2002 to enact national security laws was a godsend. According to Article 23 of the Basic Law, "The HKSAR shall enact laws on its own to prohibit any act of treason, secession, sedition, subversion against the Central People's Government, or theft of state secrets, to prohibit foreign political organizations or bodies from conducting political activities in the Region, and to prohibit political organizations or bodies of the Region from establishing ties with foreign political organizations or bodies" 6 . Human rights activists and democrats alike had always feared that the related laws would be used to curb peaceful protest in Hong Kong, especially against Hong Kong democrats who had provided so much support to the mainland dissidents during the 1989 movement.

7 The National Security (Legislative Provisions) Bill, tabled to the Legco in February 2003, was criticised by legal professionals and human rights activists as too vague and illdefined, and allegedly open to abuse by the authorities to prosecute peaceful protest in Hong Kong ${ }^{7}$. Opinion polls showed that a majority of public opinion opposed the government's proposals ${ }^{8}$. Backed by a pro-government majority in Legco, the SAR government was confident they could push through the Bill and ignored the democrats' call to delay the Second Reading of the Bill scheduled for July 9th 2003. The government's proposals led to an unprecedented mobilisation of civil society, with religious groups, professional leaders and other civil groups calling on Hong Kong citizens to oppose the legislation. Hong Kong citizens were also greatly dissatisfied with the performance of the SAR government since 1997, particularly its handling of the SARS epidemic in spring 2003, which led to 299 deaths in Hong Kong. The demonstration on July 1st 2003, a last-ditch effort to oppose the National Security Bill, became an anti-government protest on a massive scale. An estimated 500,000 Hong Kong citizens marched in the streets of Hong Kong, forcing the SAR government to withdraw the Bill days later. 
8 The movement against Article 23 quickly became a fully-fledged movement for democracy. The democrats claimed that the SAR government was not popularly elected, and would be likely therefore to defy public opinion and propose legislation that threatened basic freedoms. They also claimed that since Legco was not fully democratic, it could not effectively reflect public opinion and would enact laws that would not be in the people's interests. Article 45 of the Basic Law promises that the CE will ultimately be elected by universal suffrage, while Article 68 stipulates that all Legco will be popularly elected. Neither article specifies the timing of universal suffrage. The Basic Law only specifies the methods for electing the CE and Legco up to 2004. The democrats lost no time in pushing for election of the CE by universal suffrage in 2007, and a fully popularly-elected Legco in 2008. The July 1st demonstration, the largest social movement since 1989, gave the democrats a great confidence boost. They asserted that election of the $\mathrm{CE}$ and the whole of Legco by universal suffrage would be the best way to protect the interests of the Hong Kong people, and to cure the post-1997 governing ills of Hong Kong. Opinion polls in late 2003 showed that an overwhelming majority (as much as over $80 \%$ ) of Hong Kong citizens supported election by universal suffrage in $2007 / 08^{9}$.

Peking's changing policies towards Hong Kong

9 The rebirth of the democracy movement in Hong Kong greatly alarmed Peking as Peking has never been ready to grant full democracy to Hong Kong. After 1989, the Peking authorities were particularly suspicious of the leaders of the democracy movement in Hong Kong, who played an active role in supporting the Tiananmen movement in 1989, and had travelled abroad extensively after 1989 to criticise the Chinese government on issues of human rights and democracy. Before 2003, Peking was largely content with the situation in the HKSAR, since the democrats were kept mostly in check as a minority in Legco, their popularity declining and the movement's momentum weakening. The 500,000-people demonstration on July 1st 2003 changed this view. First and foremost Peking's leaders were concerned about the social stability of Hong Kong, fearing that the SAR government, low in legitimacy, could not handle the challenge of further mobilisation. The Central Government was also afraid that riding the tide the democrats could win a majority in the September 2004 Legco elections. The landslide victory of the democrats in the November 2003 District Council elections ${ }^{10}$ made Peking's leaders fear that a similar victory for the democrats was on the cards in September 2004. Although the CE holds most of the policy-making power in the executive-dominant system of the HKSAR, Legco could still thwart government initiatives by vetoing government bills and the annual budget, possibly meaning the Centre losing control over the situation in Hong Kong.

10 The Central Government began to take more initiative in Hong Kong affairs. To forestall a possible landslide for the democrats in the 2004 election, Peking began to change both its economic and political strategies towards Hong Kong. It began to step up measures to help Hong Kong's economy recover. To the leaders in Peking, much of the anti-government sentiment in Hong Kong was due to the economic downturn after 1997 and the inability of the SAR government to deal with it. They believed a rapid economic recovery would weaken the appeal of the pro-democracy opposition and would also help the pro-government/pro-Peking parties who had shared part of the blame for the unsatisfactory performance of the SAR government. 
11 Economic assistance plans had been under consideration for some time, but after July 2003 the Central Government took steps to speed up the process. Key in the economic assistance proposals was the Closer Economic Partnership Agreement (CEPA) between the mainland and Hong Kong ${ }^{11}$. Hong Kong companies in the service sectors, including management consultancy, real estate and construction, healthcare, law, banking, accounting, etc., were given access to the Guangdong market by the CEPA agreement signed in September 2003. Hong Kong's exports to Guangdong would face zero tariffs, with similar benefits soon to be extended to exports to other provinces. The Central Government also relaxed its controls on mainland tourists coming to Hong Kong. Starting from July 2003, tourists from four mainland cities (Dongguan, Foshan, Jiangmen and Zhongshan) were allowed to come to Hong Kong on their own, not obliged to visit only on a state-organised tour. In 2004, this "individual tourism" scheme was extended to more mainland cities, immediately boosting Hong Kong's tourist income. This was followed by a series of infrastructure projects that would speed up the integration of Hong Kong with the Pearl River Delta region, including a Hong Kong-Zhuhai-Macau bridge which many believed would strengthen Hong Kong's status as the logistics hub of southern China. In addition to aiding a quicker recovery of Hong Kong's economy, these measures could show that the Central Government cared about and was willing to help Hong Kong. Increased economic integration between Hong Kong and the mainland also made the business and professional sectors in Hong Kong more dependent on the mainland for business opportunities, which allowed the Central Government to wield more formal and informal influence on the local elites ${ }^{12}$.

On the political front, Peking tried to kill off hopes for full democracy in 2007/08 before the elections, so that the democrats could not use the political goal as the campaign issue of the 2004 election. Peking began a barrage of propaganda against the Hong Kong democrats in early 2004 through a series of articles in mainland mouthpieces such as the China Daily, People's Daily and the Xinhua News Agency. The articles accused the democrats of being unpatriotic, of inviting foreign intervention in Hong Kong affairs, and of trying to change the mainland socialist system. They claimed that Hong Kong could only be governed by people who "love China, love Hong Kong" (WWWW, aiguo aigang), and it would be dangerous for Hong Kong to have full democracy if the elections could not guarantee that those elected are aiguo aigang ${ }^{13}$.

In April 2004, the Standing Committee of the National People's Congress (NPCSC) virtually eliminated the possibility of full democracy in 2007/08 by handing down a new interpretation of the Basic Law. The NPCSC resolved that although the methods of election for the $2007 \mathrm{CE}$ and the 2008 Legco could be changed, the CE in 2007 and Legco in 2008 would not be fully elected by universal suffrage. The NPCSC further ruled that the proportion of popularly elected seats and functional seats would remain unchanged in the 2008 Legco elections, meaning that each would make up half of Legco in 2008-2012. Democrats in Hong Kong criticised the resolution as a blatant violation of the "One Country, Two Systems" principle and the autonomy of Hong Kong, as the Basic Law did not say that the NPCSC can decide the scope and pace of political reform for the SAR ${ }^{14}$.

It was also reported that the mainland authorities were actively involved in helping the pro-Peking parties in the 2004 election. In April and May 2004, it was widely reported in Hong Kong that mainland officials had put pressure on Hong Kong citizens who worked on the mainland, forcing the latter to mobilise their relatives and friends to register as 
voters. Mainland officials also reportedly told Hong Kong businessmen to pressure their employees to vote for pro-Peking candidates in the September election ${ }^{15}$. Mainland city and county officials visited Hong Kong and met the corresponding hometown associations before the election, allegedly asking the associations to mobilise their members to vote for the pro-Peking candidates ${ }^{16}$. There were also complaints that mainland officials had asked employees from Hong Kong to send photos of their ballot paper by mobile phone to prove they had voted for pro-Peking candidates ${ }^{17}$.

Back in Hong Kong, after July 2003 the SAR government largely refrained from raising controversial policies, for fear of stirring further social mobilisation against the government, which they believed would only benefit the democrats. In September 2003 the SAR government announced that it would not raise the National Security Bill before the 2004 election, although in doing so it would risk never being able to pass it again should the democrats get a majority in Legco after the election. In the 2004/05 annual budget, the Financial Secretary did not raise any taxes, despite a looming budget deficit of HK\$49 billion in the 2003/04 financial year. The government also announced that it would postpone its original plans to balance the budget by 2007 to 2008/09, thus alleviating immediate pressure on the government to cut back on social services and civil service salaries. The general strategy was to refrain from taking controversial action nearing election time, to avoid giving further ammunition to the political opposition to fan anti-government sentiments.

The campaign Co-ordination within the two camps

Both the pro-democracy camp and the pro-Peking camp put a great deal of effort into co-ordinating their candidates within their camps before the election. Hong Kong adopted a proportional representation system for the 30 popularly-elected seats, with Hong Kong divided into five constituencies, each electing four to eight Legco members. The seats were allocated roughly in accordance with the proportion of votes obtained by a party/candidate list. With the large number of pro-democracy groups and candidates willing to run in the election, the democrats thought it was of utmost importance that they co-ordinated their candidates so that they would not overnominate and hurt their own chances. Political science professor Joseph Cheng and Reverend Chu Yiu-ming took up the next-to-impossible task of liaising among the various candidates. The task mostly involved asking candidates deemed to have little chance of winning to withdraw, and finding suitable candidates to contest the functional constituencies (in which the democrats had seldom participated before), deciding if the pro-democracy candidates should be put onto one list or split across different lists, and avoiding clashes between pro-democracy big guns. Both Cheng and Chu admitted that the exercise has not been totally successful, as nobody in the prodemocracy camp had an overriding authority to dictate the candidate nomination within so many parties/groupings. But they saw the experience as positive, as the preelection liaisons provided a platform for the democrats to discuss their differences, which minimised bickering in their camp during the campaign ${ }^{18}$. In the end, agreeing to disagree, the pro-democracy camp ran 19 different lists in the five constituencies, and fielded candidates to contest 11 functional constituencies.

In comparison, the pro-Peking camp had a relative success asking weaker candidates to withdraw. Candidates such as David Chu and Tang Shiu-tang, both incumbents from the conservative Hong Kong Progressive Alliance (HKPA), withdrew shortly before the 
election ${ }^{19}$. The DAB also liaised with the pro-business Liberal Party (LP) in the functional constituencies to avoid mutual competition and vote-splitting. It was reported that the Central Government Liaison Office (CGLO) ${ }^{20}$ had been working hard to liaise between different pro-Peking groups to work out the best co-ordination between them ${ }^{21}$.

The campaign issue

The major campaign issue of the 2004 election was, unsurprisingly, democratisation. Although it did not sound very hopeful, the democrats ran on a common platform of "universal suffrage for 2007/08". The democrats claimed that there was still ample time before 2007 to persuade the Central Government to change its mind on the issue of universal suffrage. Specifically, the democrats claimed that if they could win a majority or close to a majority in the Legco elections, it would strengthen their hand in bargaining for universal suffrage with the Central Government. Seeing the election as an important landmark in the democracy movement, the democrats urged the voters to treat the election as a referendum on democracy and cast their vote in support of democracy for Hong Kong.

The pro-Peking camp was relatively defensive on the issue of political reform. They claimed that it was unrealistic to insist on full democracy in 2007/08 now that the NPCSC had handed down its verdict. The largest pro-Peking party, the DAB, claimed that "stability" and "harmony" as most important for Hong Kong's development, a campaign theme they had used in the 2000 elections. They accused the democrats of being too confrontational against both the Central and the SAR governments, which they claimed would only hurt Hong Kong's stability and harmony. They warned that if the democrats won a majority, government initiatives would face much undue opposition, which would lead to a paralysis of the government. The conservatives asserted that Hong Kong should focus its energies on economic recovery, and they could better help, compared to the democrats, to revive Hong Kong's economy by making constructive proposals to the SAR and Central governments. On the issue of political reform, most conservatives said they now supported universal suffrage for both the CE and Legco in 2012.

During the campaign the pro-democracy candidates relentlessly attacked the conservatives' stand on democratisation and their past records in supporting the government's unpopular policies and Article 23. They branded the pro-government candidates the "Royalists", pointing to their past record of supporting government decisions at all costs. The democrats also told the voters not to trust the conservatives' platform of universal suffrage by 2012 . They claimed that the pro-Peking politicians would always obey Peking's orders, so if Peking later refuted democracy by 2012, the pro-Peking parties would change their positions again. Veteran democrat Martin Lee, former DP Chairman, teased that DAB was the acronym for "Democracy According to Beijing". The conservatives retorted that political reform must be gradual to ensure stability and harmony, that all reform must be approved by Peking, and that Hong Kong was not ripe for full democracy. Instead they said that Hong Kong should focus on economic revival for the time being. Campaign-wise the pro-Peking DAB mostly focused on district-level constituency services. Mobilisation by intermediary organisations, such as the pro-Peking labour unions ${ }^{22}$, China-funded enterprises, conservative neighbourhood or kaifong organisations, rural committees, and other pro-Peking mass organisations, was the DAB's strong suit. 
Negative campaigning

21 At later stages of the campaign, scandals involving candidates stole the limelight. On August 16th, a DP candidate, Alex Ho, was arrested in the mainland city of Dongguan, for allegedly hiring a prostitute, and was sent without trial into "administrative detention" for six months. The DP claimed a political set-up. Four days before the election, Dongguan police released "evidence" of Ho's arrest, showing pictures of a bare-chested Ho against a background of a hotel room. In late August, it was revealed that DP incumbent legislator James To had used government allowances to buy private premises for his ward office, and had not declared his ownership of shares of a company as stipulated by law. That James To's explanation and records of related transactions were so unclear and confusing raised serious suspicions that he or the DP had misused government funds to buy premises for themselves. One week later, Chen Yuen-han, a DAB heavyweight, was involved in a scandal similar to To's, but the case received far less media coverage largely due to self-censorship by the pro-Peking papers and media in Hong Kong.

The scandals dealt a certain blow to the DP's popularity, credibility, and moral image. Tracking polls showed that the DP candidate lists in the two constituencies involved suffered a decline in voter support by $5-10 \%$, with DP lists in other districts suffering a smaller loss. The loss by DP may not have benefited the pro-Peking camp tremendously, as polls showed that the lost votes were mostly picked up by other prodemocracy candidates.

Analysis of the results

On September 12th 2004, a record 1.78 million Hong Kong citizens cast their votes in the semi-democratic Legco elections, with a record turnout of 55.6\%. There were quite a few irregularities on polling day. In the afternoon some polling stations declared that they had no more ballot boxes, and some stations had to be closed for some 45 minutes and voters were turned away. Some candidates complained that polling station officials had opened ballot boxes to "squash" the ballot papers so that the boxes could accommodate more ballot papers, without the consent of the candidates' agents. The authorities took some eight hours to release the exact voter turnout figures on polling day $^{23}$. In some constituencies, there were discrepancies between the number of ballots cast and the number of ballots given out. Despite all these irregularities, the SAR government insisted the election was fair.

The polling result was a disappointment for the democrats. They won only 25 seats, far from the majority they had hoped for. The pro-democracy flagship DP actually saw their seats reduced from 11 to 9, although other democrats gained ground. On the whole, the pro-democracy camp picked up only one extra seat from the popular election battlefront, and two from the FCs. The DP's major political rivals, the DAB and the pro-business conservative Liberal Party (LP), both gained seats despite the unfavourable political climate. The pro-Peking DAB won two extra seats, increasing their total seats from 10 to 12 and became the largest party in Legco. The LP kept all their eight seats in the FCs, and managed to win two seats in the popular elections for their Chairman James Tien and Vice Chairlady Selina Chow. Overall, the progovernment majority was secured but somewhat reduced in margin, with the progovernment bloc taking up some 31-32 votes in the new Legco.

The international media commonly saw the election as a victory for the pro-Peking camp and a setback for the democrats. Strictly speaking this was inaccurate. The pro- 
democracy camp in fact won a minor increase in the overall vote share (see Table 2) from $57 \%$ to $60.6 \%$, although the increase was smaller than they had hoped for. The DAB won a lower share of the vote than in 2000 , down from $30 \%$ to $25 \%$, although the decrease was less than expected. The DAB picked up extra seats largely because they managed to keep the original share of the vote in three of the constituencies, and picked up the new seat added in those constituencies. With about $60 \%$ of the popular vote, the democrats won $60 \%$ (18 out of 30 ) of the popularly-elected seats, which was about right under the proportional representation system. They could have won one more seat if not for a tactical mistake in the Hong Kong Island constituency ${ }^{24}$, even so they could only have won a total 26 seats and could not have won a majority.

\section{Vote share}

\begin{tabular}{|c|c|c|c|c|c|}
\hline & 1991 & 1995 & 1998 & 2000 & 2004 \\
\hline Democrats & 64.6 & 61.4 & 64.4 & 57.11 & 60.6 \\
\hline $\begin{array}{l}\text { Pro-Peking } \\
\text { conservative }\end{array}$ & 25.2 & 35.2 & 31.0 & $34.4:$ & 37.1 \\
\hline $\begin{array}{l}\text { Moderates / } \\
\text { independent! }\end{array}$ & 10.0 & 3.28 & 4.57 & 8.42 & 2.08 \\
\hline
\end{tabular}

Comparing the vote shares obtained by the different political camps since 1991 (Table 2), we can see that the conservatives gained ground in the 2004 elections at the expense of the moderates/independents. In particular, candidates such as Rita Fan, Legco president since 1997, and LP heavyweights James Tien and Selina Chow, all Legco veterans for some twenty years running for direct election for the first time, attracted much of the moderate-conservative voters. Under heavy mobilisation by the proPeking camp, the democrats managed to hold their turf and made modest gains, but the independents and moderates, who had tried to hold the middle ground between the two camps, with no sizeable organisational support, lost out ${ }^{25}$. The rebirth of the democracy movement since July 2003 may have rescued the continual decline of the pro-democracy parties after 1997, but their popularity has not quite returned to pre-1997 levels. Generally speaking, over the years the democrats have consolidated support of around $60 \%$, remarkable by international standards. This showed that a majority in Hong Kong consistently supported the democrats and/or a faster pace of democratisation, but the semi-democratic nature of the system prevented the democrats from gaining either a legislative majority or executive power.

There were other positive signs for the democrats. They picked up two new seats in two functional constituencies that represent accountants and medical doctors respectively. Before the election, the democrats had held five seats in the FCs. The two new seats mean that the democrats now represent seven of the nine professional sectors in the FCs, which testifies to the support of the middle class and professionals for democracy ${ }^{26}$.

Several factors could explain the failure of the democrats to make more significant gains. The April verdict of the NPCSC certainly took the wind out of the democrats' 
sails. While most Hong Kong people would still support universal suffrage in 2007/08, most knew that it was not very hopeful and the mobilisation effect of the campaign theme was somewhat reduced. The democrats' common platform on universal suffrage managed to consolidate basic support for the democrats (which should form a large part of that $60 \%$ share of the vote), but was perhaps unable to win over the moderates or middle-of-the-roaders who might have voted according to other non-political criteria or were focused more on livelihood issues. Short in resources, the democrats were in general weaker in mobilisation power compared with the conservative camp, and relied mostly on cognitive mobilisation ${ }^{27}$. A minor rebound of the economy in the summer of 2004, partly due to individual tourism and recovery from the doldrums of the 2003 SARS epidemic, created some optimism and weakened anti-government sentiment ${ }^{28}$. Polling results showed that conservative figures that had a more upper/ middle class appeal such as Rita Fan or LP candidates obtained decent support in middle-class precincts, which were traditionally strongholds of the democrats. On the whole, the strategy by the Central Government might have worked in preventing the democrats winning a resounding victory. Under the proportional representation system, and with the democrats unable to capture too many seats in the FCs, the democrats may need a vote share of more than $70 \%$ to seize a majority, very difficult on all counts.

The outcome of the election saw a pluralisation of the political spectrum in Hong Kong. With the increase in popularly elected seats, the proportional representation system began to show its effect in representing a more diversified political spectrum. Traditionally, Hong Kong's political forces were largely divided between the prodemocracy and the pro-Peking camps ${ }^{29}$. Due to the economic downturn, the public began to pay more attention to bread-and-butter issues after 1997. A social-democratic political field rose within the pro-democracy camp, as pro-democracy labour unionists such as Lee Cheuk-yan and pro-labour politicians such as Leung Yiu-chung began to distance themselves from the DP on class issues ${ }^{30}$. The 2004 elections returned more pro-labour democrats to Legco, including prominent anti-government figures such as Albert Cheng and Leung Kwok-hung (better known as "Long Hair" in the territory). The former was a famous talk-show host who achieved part of his immense popularity through his vitriolic criticisms of the SAR government and officials. The latter was a self-proclaimed Trotskyist who had long engaged in street protests against the Central and the SAR governments. On the other hand, the struggle against Article 23 saw a rise in popularity of some of the prominent barristers in the territory. They and other legal professionals formed the Article 45 Concern Group which won four seats in the 2004 elections. Figure 1 shows the new political spectrum. 


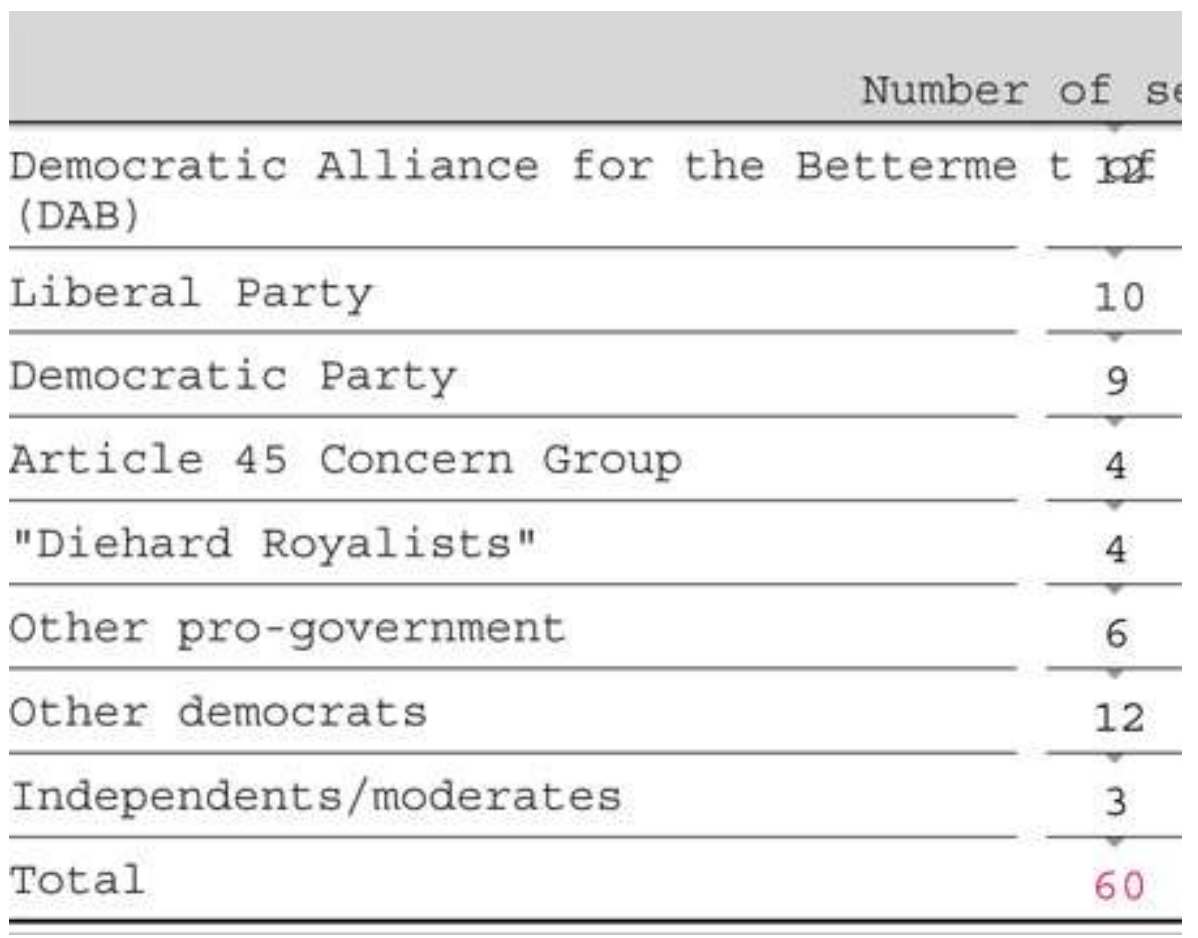

The DP saw its political influence diminished after the elections, both in Legco and within the pro-democracy camp. Having been the flagship of the pro-democracy camp since 1994, the DP still made up half of the 22 pro-democracy seats in the 2000-04 Legco. The 2004 elections saw the DP's share of the vote further drop from $35 \%$ in 2000 to $25.8 \%$, from 11 seats to 9 , and it now only held about one-third of the 25 Legco seats in the pro-democracy camp. The pro-democracy camp was on the whole more pluralised, with legislators who could use more radical action to challenge the government, and more moderate barristers likely to share similar views on class issues with the pro-business parties.

Impact on future political developments

Peking should be reasonably satisfied with the results of the 2004 elections, with the democrats failing to get even close to a majority, and the pro-Peking candidates achieving good results. Although the democrats still won a majority of the popular vote, their less-than-satisfactory showing in the election weakened their claims of a strong mandate for universal suffrage in 2007/08. The democrats' failure to make extra ground trapped them in the position of being a "permanent minority" and weakened their bargaining power vis-à-vis the Central and SAR governments on the issue of future political reform. The results make give the Central Government less incentive to make concessions to the democrats on the upcoming reform proposals for the 2007/08 elections. It is unlikely that Peking will change its mind on the issue of universal suffrage in 2007/08, and the election results might serve to further delay political reform in the territory.

Democratic development in Hong Kong was at a stalemate after the 2004 elections. The democrats were not strong enough to force a faster pace of democratisation, and the election results will be unlikely to encourage Peking's leaders to speed up reforms in Hong Kong. Further delay in political reform, however, could only prolong and 
aggravate the SAR government's governance and legitimacy problems. The irony of the political situation in Hong Kong is that the political grouping that consistently won $60 \%$ or more of popular support is a permanent minority in the legislature, and almost totally shunned from executive office. This creates a perpetual credibility problem for the SAR government, made all the more apparent by recent democracy movements and post-1997 government problems. Without more fundamental political reforms, this will continue to haunt SAR governance.

In the short term, the SAR government is likely to face more challenges after September 2004 than was commonly believed. The government's majority in Legco was somewhat reduced. Some of the moderates/independents, who do not belong to the pro-democracy camp, may not be able to be counted on to support the government every time ${ }^{31}$. On the whole Legco's more pluralised and fragmented make-up may increase the government's difficulties in lobbying for majority support for controversial bills and legislation. Some of the more radical members such as Long Hair and Albert Cheng may still pose serious challenges to the authority and legitimacy of the SAR government. Even though Peking and the SAR government got the result they wanted, the outcome of the September 2004 Legco elections will not help the SAR government solve its most fundamental problems of governance.

\section{Political distribution in the new Legco}

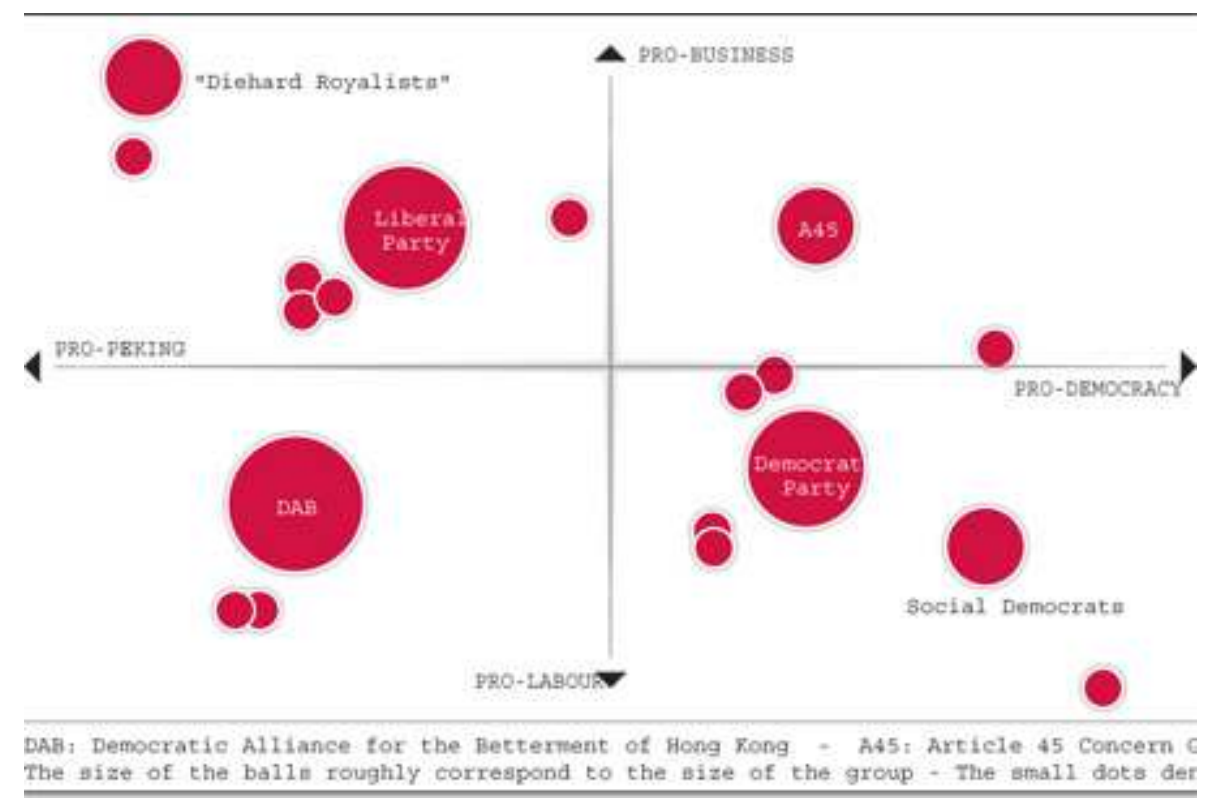

\section{NOTES}

http://www.info.gov.hk/censtatd/chinese/hkstat/fas/labour/ghs/labour1_index.html 


\section{NOTES DE FIN}

1. Ambrose King, "Administrative Absorption of Politics in Hong Kong: Emphasis on the Grassroots Level”, Asian Survey, No. 15, 1975, pp. 422-439.

2. See Sing Ming, "Economic Development, Civil Society and Democratization in Hong Kong", Journal of Contemporary Asia, Vol. 26, No. 4, 1996, pp. 482-504; Sing Ming, Hong Kong's Tortuous Democratisation: A Comparative Analysis, London, RoutledgeCurzon, 2004.

3. See, for example, Alvin So, “The Tiananmen Incident, Patten's Electoral Reforms, and the Roots of Contested Democracy in Hong Kong", in Ming K. Chan (ed.), The Challenge of Hong Kong's Reintegration with China, Hong Kong, Hong Kong University Press, pp. 49-83; Ming K. Chan, "Democracy De-railed: Realpolitik in the Making of the Hong Kong Basic Law, 1985-90", in Ming K. Chan and David Clark (eds.), The Hong Kong Basic Law: Blueprint for "Stability and Prosperity" under Chinese Sovereignty, Hong Kong, Hong Kong University Press, pp. 3-35; Sing Ming, Hong Kong's Tortuous Democratisation, op. cit.; Hsin-chi Kuan, "Power Dependence and Democratic Transition: The Case of Hong Kong", The China Quarterly, No. 128, 1991, pp. 774-793.

4. See Ma Ngok, "The Decline of the Democratic Party in Hong Kong: The Second Legislative Election in the HKSAR", Asian Survey, Vol. 41, No. 4, July/August 2001, pp. 564-583.

5. See Ma Ngok, "Factionalism in the Democratic Party and the 2000 Election," in Kuan Hsin-chi, Lau Siu-kai and Timothy Ka-ying Wong (eds.), Out of the Shadow of 1997? The Legislative Council Election in the Hong Kong Special Administrative Region, Hong Kong, Chinese University Press, pp. 125-159.

6. The original draft of the article in 1988 forbade only secession or subversion. After Tiananmen, the central authorities added other provisions. See Hong Kong Human Rights Monitor, A Ticking Time Bomb? Article 23, Security Law, and Human Rights in Hong Kong, Hong Kong, Hong Kong Human Rights Monitor, 2001, p. 8.

7. For contents of the Bill and the related debates, see Ma Ngok, "Civil Society in SelfDefense: The Struggle Against National Security Legislation in Hong Kong", Journal of Contemporary China (Forthcoming).

8. For example, in December 2002 an opinion poll showed that $54 \%$ of Hong Kong people were opposed to the government proposals, with only $20 \%$ supporting. Ming Pao Daily News, December 14th 2002, p. A10.

9. Opinion polls by the Public Opinion Program of University of Hong Kong in November 2003 showed that $80 \%$ of those who voted in the November 2003 District Council supported electing the $2007 \mathrm{CE}$ by universal suffrage, with $85 \%$ supporting electing the whole of Legco by universal suffrage. See Hong Kong Economic Times, January 26th 2004, p. A23.

10. The District Councils are district-level advisory bodies who have a very limited budget for local environmental work but no executive power. By 2003, 400 of the 529 District Councillors were popularly elected. Traditionally the pro-Peking conservatives had the upper hand in these very local elections, as they were more resourceful in cultivating the local patron-client networks. However, a record voter turnout of $44 \%$ in the November 2003 District Council election brought a landslide victory for the democrats. The largest pro-Peking party, the DAB, fielded 206 candidates and only 62 of them won, a success rate of only $37.8 \%$. In contrast, the pro-democracy flagship the 
Democratic Party had 92 of their 120 candidates elected, a stunning success rate of 79.1\%.

11. Bruno Cabrillac, "A Bilateral Trade Agreement Between Hong Kong and China: CEPA", China Perspectives, No. 54, July-August 2004, pp. 39-47.

12. Ian Holliday, Ma Ngok and Ray Yep, “After 1997: The Dialectics of Hong Kong Dependence”, Journal of Contemporary Asia, Vol. 34, No. 2, 2004, pp. 254-270. 13. For essays and articles on the "patriotism debate", see Ming Pao Editorial Department ed., The Patriotism Polemic (Aiguo Lunzheng), Hong Kong, Ming Pao Publishers, 2004.

14. Annex II of the Basic Law stipulates that if the SAR wants to change the method of election for the CE after 2007, the change must be approved by the NPCSC. A change to the method of election for the Legco needs to be reported to the NPCSC "for the record." There is no provision in the Basic Law which says that the NPCSC should decide the contents of the constitutional changes on behalf of the SAR.

15. Apple Daily, April 26th 2004, p. A6; Apple Daily, April 27th 2004, p. A4.

16. See Ming Pao Daily News, May 14th 2004, p. A2.

17. Hong Kong Economic Times, May 14th 2004, p. A21.

18. Author's interview with Joseph Cheng and Rev Chu.

19. The Sun, July 24 th 2004 , p. A6.

20. Before 1997, the New China News Agency in Hong Kong served as the de facto embassy of China in Hong Kong, which also was the headquarters of the Hong Kong and Macau Working Committee of the Chinese Communist Party, the CCP's party branch in Hong Kong. After 1997, it was renamed the Central Government Liaison Office, which should handle all the CCP party work in Hong Kong after 1997.

21. Sing Pao Daily News, March 27th 2004, p. A3; Sing Tao Daily News, July 28th 2004, p. A6. 22. As the largest federation of trade unions in Hong Kong, the Hong Kong Federation of Trade Unions (HKFTU) boasted a total membership of over 300,000.

23. In past elections the government usually could give the exact turnout figures within two hours after the polling stations were closed.

24. In the Hong Kong Island constituency, opinion polls in the last weeks of the campaign showed that the list of democrat Audrey Eu and Cyd Ho was leading by a comfortable margin, while the DP list of Yeung Sum and Martin Lee was leading the DAB list by a relatively slim margin. The DP gave out crisis warnings in later stages of the campaign, claiming that Martin Lee, as second candidate on the DP list, could possibly lose his seat. The strategy backfired as too many pro-democracy supporters deserted Audrey Eu's list at the last minute, and Cyd Ho lost her seat by the slimmest margin of $0.3 \%$ or 800 votes. In the end, the two pro-democracy lists, while getting close to $60 \%$ of the vote, only won three of the six seats, while the pro-Peking candidates won three seats with $36 \%$ of the votes.

25. A good example was Andrew Wong, public policy lecturer and a 19-year veteran legislator who in the past was well supported by both moderate voters and rural and district-level conservatives. In the 2000 election he obtained $14 \%$ of the popular vote in the New Territories East constituency and was elected, while in 2004 he got only 5.4\%, with most of the rural and local conservatives deserting him, losing his seat.

26. Of the 30 seats elected by functional constituencies, nine of them are elected by professionals on a one-person-one-vote basis. These include the sectors that represent schoolteachers, lawyers, information technology, social workers, health workers (mostly nurses), accountants, medical doctors, engineers, and architectural and related 
professions. Other FC seats are mostly elected by corporations or groups, which made it difficult for the democrats to compete as the seats are usually stitched up by the related chambers of commerce or sectoral associations.

27. Kuan Hsin-chi and Lau Siu-kai, "Cognitive Mobilization and Electoral Support for the Democratic Party in Hong Kong", Electoral Studies, No. 21, 2002, pp. 561-582.

28. The unemployment rate in June-August 2004 was $6.8 \%$, down from the post-1997 high of $8.6 \%$ in April-June 2003. GDP growth was $2.6 \%$ for the second quarter of 2004 . See the following websites of the SAR government for further information: http:// www.info.gov.hk/censtatd/chinese/hkstat/fas/nat_account/gdp/gdp1_index.html

\section{RÉSUMÉS}

The Democrats in Hong Kong failed to gain significant ground in the September 2004 Legislative Council Elections, making only modest gains and falling far short of the legislative majority they had hoped for. This result made it difficult for the Democrats to claim a strong mandate for more progressive democratisation, weakening their bargaining power vis-à-vis Peking, which may in its turn induce Peking to further delay political reform in Hong Kong. The election results, however, did little to alleviate the governing crisis of the Hong Kong government, and a more pluralised post-election legislature created new headaches for the government. 